Send your letters to the Editor,

British Dental Journal,

64 Wimpole Street

London

W1G 8YS

Email bdj@bda.org

Priority will be given to letters less than 500 words long.

Authors must sign the letter, which

may be edited for reasons of space.

\section{STEM CELL VISITS}

Sir, I note the report of research in which Tamaoki et al. have successfully induced pluripotent stem cells from dental pulp cells (BDJ 2010; 209: 5). The original discovery of stem cells in the dental pulp was by S. Shi's team at the NHI, Maryland, USA in 2003.

As a direct result of this research a process for extracting, magnifying and storing these cells was patented and became the cornerstone of the process of Bioeden Ltd, Austin, Texas which stores cells naturally acquired from recently shed deciduous teeth. This is the only known way of achieving access to healthy stem cells which is both natural and non-invasive, consequently meeting with the approval of all mainstream religions and cultures.

Consequently, stem cells are now stored for thousands of children and young adults from more than 20 countries and research-based medical therapies using dental pulp cells have successfully taken place already in Italy and Mexico City. ${ }^{2}$

Bioeden Ltd currently has its international headquarters in Daresbury, Cheshire - and, as would be expected, has extensive relationships with dentists both in the UK and overseas.

In addition to my directorship with Bioeden Ltd I also enjoy my continuing involvement in dental practice, and should any of the journal's readers like to visit our laboratories and hear more about our company I should be delighted to organise such a visit for them.

D. James

Director, Bioeden Ltd,

Chester Cosmetic Dental Centre david.james@bioeden.com

1. Miura M, Gronthos S, Zhao M et al. SHED: stem cells from human exfoliated deciduous teeth. Proc
Natl Acad Sci U S A 2003; 100: 5807-5812. 2. d'Aquino R, Papaccio G, Laino G, Graziano A. Dental pulp stem cells: a promising tool for bone regeneration. Stem Cell Rev 2008; 4: 21-26.

DOI: $10.1038 /$ sj.bdj.2010.821

\section{DEVELOPING THE TEAM}

Sir, the British Society of Dental Hygiene and Therapy (BSDHT) recently hosted the 18th International Symposium on Dental Hygiene (ISDH) under the auspices of the International Federation of Dental Hygienists in Glasgow. It attracted over 1,100 people from 36 countries making it the largest international symposium to date. It was an event made possible by the excellent teamwork from many people and organisations. The scientific programme proved first class and delegates enjoyed some of the most information rich continual professional development it's possible to generate.

ISDH 2010 enjoyed considerable support from the dental industry who not only participated in the exhibition but the following were also principal sponsors of the symposium: Colgate, Johnson and Johnson, Philips, Procter and Gamble Oral Health Care, GlaxoSmithKline, Tepe NSK, Sunstar and Dentsply.

The British Dental Association (BDA) along with the British Dental Trade Association (BDTA) can also be thanked for their support. In fact this was highlighted by our international colleagues, how in the United Kingdom we are truly developing the dental team and the co-operation between all dental professionals is becoming the envy of other countries. At a time of uncertainty within the profession, from a global prospective what is certain is that in the United Kingdom we are being recognised as the world leader in developing the role of the dental team. Credit must go to the BDA, BDTA and the Department of
Health for continuing to facilitate change and recognise the true value of the role of all members of the dental team.

M. Wheeler

ISDH 2010 Event Director DOI: 10.1038/sj.bdj.2010.822

\section{DOWN THE DRAIN}

Sir, in this time of austerity, is the profession acting ecologically responsibly? No doubt others have mused over this conundrum, and the possible impact of HTM 01-05. According to the BDA there are around 11,000 dental practices in the country, and no doubt hospital and community services will add a further 500 units. If we consider water usage, each unit following HTM 01-05 will have an ultrasonic bath, a washer disinfector and an autoclave. Water usage will vary between models, but as an example they could use 6, 14.5 (per cycle) and 3.5 (discharged at the end of the day) litres per day. If five cycles of the washer disinfector are undertaken, a total of 82 litres of water (ignoring that from the air rota use) will go down the drain each day per unit. A total of 943,000 litres from all dental units per day. As an Olympic size swimming pool holds approximately 2,500,000 litres of water, we could be discharging over one third of a swimming pools volume of water down the drain each day. No wonder the reservoirs are drying up. In addition to this there is the 2,800 litres of ultrasonic cleaner and 2,800 litres of washer disinfector detergent each day, both of which the water companies will have to remove before the water can be reused or discharged back into the environment. This leads on to consideration of the weight of chemicals and energy used in providing the water fit to drink in the first place, which is quite considerable. 